\title{
Evaluation of Sodicity Indices for Non-saline Sodic Soils of Ramthal Micro Irrigation Project Area of UKP and their Associated Risks for Horticultural Crops
}

\author{
P.D. Lakshmi*, M.S. Nagaraja, Shankara Meti, R. Suma, \\ C.N. Pallavi and Anita E. Kondi \\ Department of Soil Science and Agricultural Chemistry, College of Horticulture, University of \\ Horticultural Sciences, Bagalkot, 587104, India \\ *Corresponding author
}

\section{A B S T R A C T}

\section{Keywords}

Sodicity indices, SAR, RSC,

Vertisols, Northern

Karnataka

Article Info

Accepted:

04 January 2019

Available Online:

10 February 2019
The presence of salts in soil is a common phenomenon. However, the extent of salts in a soil is determined by soil type and the prevailing regional climate. The seasonal rainfall and irrigation practices will alter the salt dynamics. A study was conducted in a small area of the country's largest micro-irrigation project - Ramthal Micro Irrigation Project of UKP command. About 500 ha of the project area with about $25 \mathrm{~m}$ elevation was covered and assessed for sodification risks. The sodicity indices viz. SAR, RSC, SSP and alkalinity fraction were evaluated and compared with their elevation and slope factors. The soils existing on flat and slope lands of high elevated areas were found prone for sodification with higher sodicity indices. Contrastingly, the soil at lower elevation recorded lesser sodicity. Solubility and precipitation reactions of different salts in the region might have caused variation in sodicity indices. Though, the extent of soil salinity appears to be low, there is risk of sodicity in the region. Thus, the selection of sodicity tolerant crops remains crucial to make the project more successful.

\section{Introduction}

The occurrence of salts in soil is a common phenomenon. However, the extent of salts in a soil depends on the prevailing regional environmental and soil factors (Sharma and Chaudhary, 2012). Soils with higher amounts of water soluble salts can cause yield reductions and hence, they are categorized as salt affected soils. Presence of higher amounts of salts of $\mathrm{Ca}^{2+}, \mathrm{Mg}^{2+}, \mathrm{Na}^{+}, \mathrm{K}^{+}$and $\mathrm{Cl}^{-1}, \mathrm{SO}_{4}{ }^{-}$ ${ }^{2}, \mathrm{NO}_{3}^{-1}, \mathrm{HCO}_{3}^{-1}, \mathrm{CO}_{3}^{-2}$ etc. make them saline soils while, dominance of $\mathrm{HCO}_{3}{ }^{-1}$ and $\mathrm{CO}_{3}{ }^{-2}$ of Na make them sodic soils (Chaabra, 1996; Rengasamy and Sumner, 1998). Occurrence of sodic soils with low salt content is also possible and often observed in semi-arid tracts (Sharma and Chaudhari, 2012). The excess of sodicity with low total salt content can also have similar effects as that of sodic soils with high salt content. Large tracts of soils of northern Karnataka possess high amounts of salts and inherently low productive due to scarcity of water as the region falls under semi-arid conditions with PET > RF. Though introduction of irrigations 
in this region have enhanced productivity, it has also induced secondary salinization (Doddamani et al., 1994; Rudramurthy and Dasog, 2001; Pradeep et al., 2006).

Upper Krishna Project was one of the ambitious projects across Krishna and executed in 1980s at Almatti, Bagalkot district to provide irrigations for large dry tracts of northern Karnataka. Lift irrigation was also adopted to lift the water to higher elevation areas so as to enhance productivity. However, the land productivity largely depends on soil fertility as determined by soil texture (Nagaraja et al., 2016), soil organic matter, soil reaction (Dattaraja et al., 2017) etc. To increase the area under irrigations further, micro irrigation concept was adopted at Ramthal in Hunugund taluka and the irrigation project was called 'Ramthal Micro Irrigation Project' with a provision of providing assured protective irrigations to 2 ha of land of each farmer of the Ramthal village cluster (command area). Considering the introduction of irrigations to the rainfed black soils, a study was carried out to assess the sodicity risks associated in the new Ramthal Micro irrigation project area by evaluating different sodicity indices in the region.

\section{Materials and Methods}

\section{Location and study area}

Hungund of Bagalkot district, coming under Northern Dry Zone of Karnataka, largely represents typical black soils and belongs to Vertisols. The topography of the study area exhibits gentle to moderate undulations and experiences sub-tropical climate with dry semi-arid conditions. The soils are mostly derived from basaltic parent materials. The mean annual temperature of the Hungund taluk ranged from 33 to $36{ }^{\circ} \mathrm{C}$ (in the last 10 years) while, the annual precipitation is extremely low with average of rainfall of about $630 \mathrm{~mm}$. Accumulation of salts in the surface is anticipated in these soils as PET > $\mathrm{RF}$ in this region. However, seasonal rainfall is likely to move these salts both vertically and laterally.

Ramthal Micro-irrigation Project Area of the Upper Krishna Project is divided into two large blocks and they are being operated by Jain Irrigations and Netafim Irrigation systems separately. Each block is divided into 22-25 zones covering an area of about 500 ha. This study was carried out in zone 20 of Netafim Project area with an elevation gradient of about 20 mtrs. The topography of the study area ranged from gentle to moderate slopes and the soils were found to be in situ formed with varying soil depths (deep soils at high elevations and shallow soils at low elevations).

\section{Categorization of soil samples}

The soil samples were categorized based on the elevation and slope of the study area. Considering the slope of $21 \mathrm{~m}$ and elevation difference from 510 to $530 \mathrm{~m}$, the soil samples were categorized into 6 groups namely, $\mathrm{L}_{1}$ : High flat lands, $\mathrm{L}_{2}$ : High slope lands, $\mathrm{L}_{3}$ : Mid flat lands, $\mathrm{L}_{4}$ : Mid slope lands, $\mathrm{L}_{5}$ : Low flat lands and $\mathrm{L}_{6}$ : Low slope lands.

\section{Collection of soil samples}

The information on land and soils of the study area prepared by NBSS \& LUP, Netafim, KSRSAC and Survey of India toposheets were used in identification of the study area. Each land unit of 2-5 ha was considered as a sampling unit in the study location. Name of the farmer, survey number and the exact position of the sampling site were recorded using Garmin GPS meter. Representative surface soil samples $(0-15 \mathrm{~cm})$ for each study unit was collected by pooling of three soil 
samples from the same sampling site. Pooled samples were mixed, cleaned (stones, roots, etc. removed) and collected about $500 \mathrm{~g}$ of soil samples. The soil samples were air dried, pounded, sieved and stored in air tight containers for further analysis.

\section{Soil-water extraction and chemical analysis}

The water soluble salts were extracted from soil-water suspension in the ratio of $1: 2$ by shaking $50 \mathrm{~g}$ soil with $100 \mathrm{ml}$ of distilled water for 30 mins. After 10 minutes, the supernatant was centrifuged at $1500 \mathrm{rpm}$ for $20 \mathrm{~min}$ and then, filtered to obtain the clear extract. These extracts were stored in refrigerator for chemical analysis. The water extractable cations namely, $\mathrm{Ca}$ and $\mathrm{Mg}$ (by Versanate titration; Baruah and Barthakur, 1999) and Na (by flame photometry; Sarma et $a l .$, 1987) were determined. Similarly, water extractable anions namely total carbonates, $\mathrm{Cl}$ and $\mathrm{SO}_{4}{ }^{2-}$ were determined by acid-base titrations, by Mohr's $\mathrm{AgNO}_{3}$ titration method and turbidometric method respectively (Sarma et al., 1987; Baruah and Barthakur, 1999).

\section{Sodicity indices}

The dominance of alkalinity forming ions viz., sodium and total carbonates $\left(\mathrm{CO}_{3}{ }^{2-}+\right.$ $\mathrm{HCO}_{3}{ }^{-}$) over calcium and magnesium determines the soil susceptibility for sodification (Chaabra, 1996; Sharma and Chaudhari, 2012). Thus, the soil chemical properties were assessed in terms of RSC Residual Sodium Carbonate; SAR - Sodium Adsorption Ratio; SSP - Soluble Sodium Percentage; and Alkalinity Fraction. The concentrations of respective ions in meq/L were used in deriving the above indices values using the following formulae.

The formulae used for different sodicity indices are given below
$\operatorname{SAR}($ in $\sqrt{m e q / l})=\frac{\mathrm{Na}}{\sqrt{(\mathrm{Ca}+\mathrm{Mg}) / 2)}}$

RSC (in meq/l) = (Total carbonates) $\left(\right.$ Total $\left.\mathrm{Ca}^{2+}+\mathrm{Mg}^{2+}\right)$

SSP (in \%) $=\frac{\mathrm{Na}}{\text { Total cations }} X 100$

Alkalinity Fraction (a ratio) $=\frac{\text { carbonates }+ \text { bicarbonates }}{\text { chlorides }+ \text { sulphates }}$

\section{Results and Discussion}

Soil reaction (pH) and Electrical conductivity $\left(\mathrm{EC}_{2.5}\right)$

The extent of two important soil electrochemical properties namely $\mathrm{pH}$ and $\mathrm{EC}$ in Ramthal Project study area are presented in Table 1 and their magnitudes across different land categories are depicted in Figure 1. The topography had influenced both $\mathrm{pH}$ and EC significantly. The soils at lower elevations $\left(\mathrm{L}_{3}\right)$ areas recorded significantly lower $\mathrm{pH}$ $(8.80 \pm 0.23)$ while, the soils existing on high elevations recorded higher $\mathrm{pH}$ values $(9.15 \pm$ $0.24)$.

The electrical conductivity $\left(\mathrm{EC}_{2.5}-1: 2.5\right.$ soil water suspension) ranged from 0.10 to 0.36 $\mathrm{dS} \mathrm{m}^{-1}$. All the soil samples in the study area were observed under non saline category with $\mathrm{EC}_{2.5}$ values of $<0.8 \mathrm{dS} \mathrm{m}^{-1}$. In Ramthal study area, nearly $64 \%(n=151)$ of soil samples recorded medium conductivity in the range of 0.15 to $0.30 \mathrm{dS} \mathrm{m} \mathrm{m}^{-1}$, while, $27 \%$ of soil samples $(n=64)$ recorded conductivity of < $0.15 \mathrm{dS} \mathrm{m}^{-1}$. Low elevation $\left(\mathrm{L}_{3}\right)$ areas recorded significantly lower EC values $(0.16$ $\pm 0.04 \mathrm{dS} \mathrm{m}^{-1}$ ) while, the soils at higher elevations $\left(\mathrm{L}_{1}\right.$ and $\left.\mathrm{L}_{2}\right)$ recorded high $\mathrm{EC}_{2.5}$ values. In general, the soils existing on of slopy lands recorded higher $\mathrm{pH}$ and conductivity values. 
The conductivity of soils reflects the amount of water soluble salts while, the soil reaction is determined by the type of ions in a given soil (Bohn et al., 2001). The presence of base forming cations such as calcium, magnesium and sodium are known to increase the soil $\mathrm{pH}$. The soils of arid and semiarid region are known to have higher amounts of salts due to low rain fall and high evapotranspiration (Chabbra, 1996). Movement and accumulation of water soluble salts is likely to be more severe in black soils. Higher $\mathrm{pH}$ and $\mathrm{EC}_{2.5}$ ratios in high elevation areas may be attributed to deep clayey soils exhibiting higher capillary movement during summer (Singh and Verma, 2016). Higher movement of carbonates and sodium salts due to their high solubility might have induced higher $\mathrm{pH}$ (Kirankumar et al., 2015; Lakshmi et al., 2018).

The soils of this region are mostly derived from basalts and lime based parent materials thus, the soils are rich in the above bases and the aridity (PET > RF) also might have contributed (Kirankumar et al., 2015; Rekha et al., 2015). Alternate wetting and drying cycles in this region encourage total carbonates and increase soil $\mathrm{pH}$ further (Pradeep et al., 2006; Shivakumar and Nagaraja, 2016). Similar values of higher $\mathrm{pH}$ in these soils were reported earlier by Doddamani et al., (1994); Rudramurthy and Dasog, (2001); Pradeep et al., (2006). Howeer, the $\mathrm{EC}_{2.5}$ values were substantially lower compared to irrigated areas (Kirankumar et al., 2015; Rekha et al., 2015; Ashwin et al., 2017).

\section{Residual sodium carbonate (RSC) and sodium adsorption ratio (SAR)}

The relative dominance of sodium and total carbonates over calcium and magnesium in soils is commonly indicated as SAR and RSC values. The RSC and SAR values are used to assess the susceptibility of a soil for sodification/ alkalization. Extent of variations in RSC and SAR values among different land categories and their spatial spread in the study area are presented in Table 2 and Figures 2.

In general, the RSC values were found in safer limits though the carbonates and bicarbonates were more than calcium and magnesium contents in soil solution. The RSC values ranged from $-1.98 \mathrm{meq}^{-1}$ in mid elevation flat lands $\left(\mathrm{L}_{3}\right)$ to $3.51 \mathrm{meq} 1^{-1}$ in high elevation flat land soils $\left(\mathrm{L}_{1}\right)$. Nearly 70 per cent of the soil samples $(n=166)$ were found with medium RSC values while, only 10 per cent of the samples recorded higher RSC values (> $2 \mathrm{meq}^{-1}$ ). Similarly, the SAR values ranged from 2.90 to $20.65(\mathrm{meq} / \mathrm{l})^{1 / 2}$. In the study area, majority of the soil samples (nearly $2 / 3^{\text {rd }}$ ) were found safe from sodification with values of $<10(\mathrm{meq} / \mathrm{l})^{1 / 2}$. However, $30 \%$ of the soil samples indicated moderate sodicity risks with $>10(\mathrm{meq} / \mathrm{l})^{1 / 2}$.

It was observed that the soils existing in high elevated areas were relatively more susceptible for sodification compared to low and mid elevated areas. The soils existing on flat and slopy lands of high elevated areas $\left(\mathrm{L}_{1}\right.$ and $\mathrm{L}_{2}$ ), exhibited significantly higher SAR values of $11.51 \pm 2.78(\mathrm{meq} / \mathrm{l})^{1 / 2}$ and $12.66 \pm$ $3.10(\mathrm{meq} / \mathrm{l})^{1 / 2}$ respectively. Least mean SAR values were observed in slopy lands $\left(\mathrm{L}_{6}\right)$ low elevation $8.78 \pm 2.09(\mathrm{meq} / \mathrm{l})^{1 / 2}$ and the values were found on par with soils existing at mid elevation and low elevation areas.

Similarly, the soils existing slopy lands existing at higher elevation $\left(\mathrm{L}_{2}\right)$ recorded significantly higher RSC values $(1.41 \pm 0.93$ meq $^{-1}$ ) followed by high elevation flat areas $\left(\mathrm{L}_{1}\right)\left(0.96 \pm 0.91 \mathrm{meq}^{-1}\right)$. Contrastingly, the soils on slopy lands at low elevations $\left(\mathrm{L}_{6}\right)$ recorded least RSC values $(0.26 \pm 1.10$ meq $\left.1^{-1}\right)$. This could be attributed to preferential adsorption of divalent $\mathrm{Ca}^{2+}$ and $\mathrm{Mg}^{2+}$ ions (Lakshmi et al., 2018; Sharanagouda et al., 2018). 
Table.1 Extent of variations in $\mathrm{pH}$ and EC of black soils of Ramthal irrigation project area

\begin{tabular}{|c|c|c|c|c|c|c|}
\hline \multirow[b]{2}{*}{ Land Category } & \multicolumn{3}{|c|}{$\mathbf{p H}$} & \multicolumn{3}{|c|}{$\mathrm{EC}\left(\mathrm{dS} \mathrm{m} \mathbf{m}^{-1}\right)$} \\
\hline & $\begin{array}{c}\text { Low } \\
(8.0 \text { - 8.5) }\end{array}$ & $\begin{array}{l}\text { Medium } \\
(8.5-9.0)\end{array}$ & $\begin{array}{l}\text { High } \\
(>9.0)\end{array}$ & $\begin{array}{c}\text { Low } \\
(<0.15)\end{array}$ & $\begin{array}{c}\text { Medium } \\
(0.21-0.30)\end{array}$ & $\begin{array}{c}\text { High } \\
(>\mathbf{0 . 3 0})\end{array}$ \\
\hline $\mathbf{L}_{1}$-High elevation flat land $(n=77)$ & - & $20(8.4)$ & $57(24.1)$ & $11(4.6)$ & $57(24.1)$ & $9(3.8)$ \\
\hline $\mathbf{L}_{2}$-High elevation sloppy land $(n=20)$ & - & $6(2.5)$ & $14(5.9)$ & $2(0.8)$ & $11(4.6)$ & $7(2.9)$ \\
\hline $\mathbf{L}_{3}$-Mid elevation flat land $(n=95)$ & $2(0.8)$ & 47 (19.9) & $46(19.4)$ & $35(14.8)$ & $57(24.5)$ & $3(0.8)$ \\
\hline $\mathrm{L}_{\mathbf{4}}$-Mid elevation slopy land $(\mathrm{n}=\mathbf{2 6})$ & $1(0.42)$ & $14(5.9)$ & $11(4.6)$ & $7(2.9)$ & $17(7.2)$ & $2(0.8)$ \\
\hline $\mathbf{L}_{5}$-Low elevation flat land $(n=11)$ & - & $9(3.8)$ & $2(0.8)$ & $8(3.3)$ & $3(1.2)$ & - \\
\hline $\mathbf{L}_{6}$-Low elevation sloppy land $(n=7)$ & - & $4(1.6)$ & $3(1.2)$ & $1(0.4)$ & $6(2.5)$ & - \\
\hline Total $(n=236)$ & $3(1.2)$ & $100(42.3)$ & $133(56.3)$ & $64(27.1)$ & $152(64.4)$ & $20(8.4)$ \\
\hline
\end{tabular}

Table.2 Extent of variations in RSC and SAR values of black soils of Ramthal project area

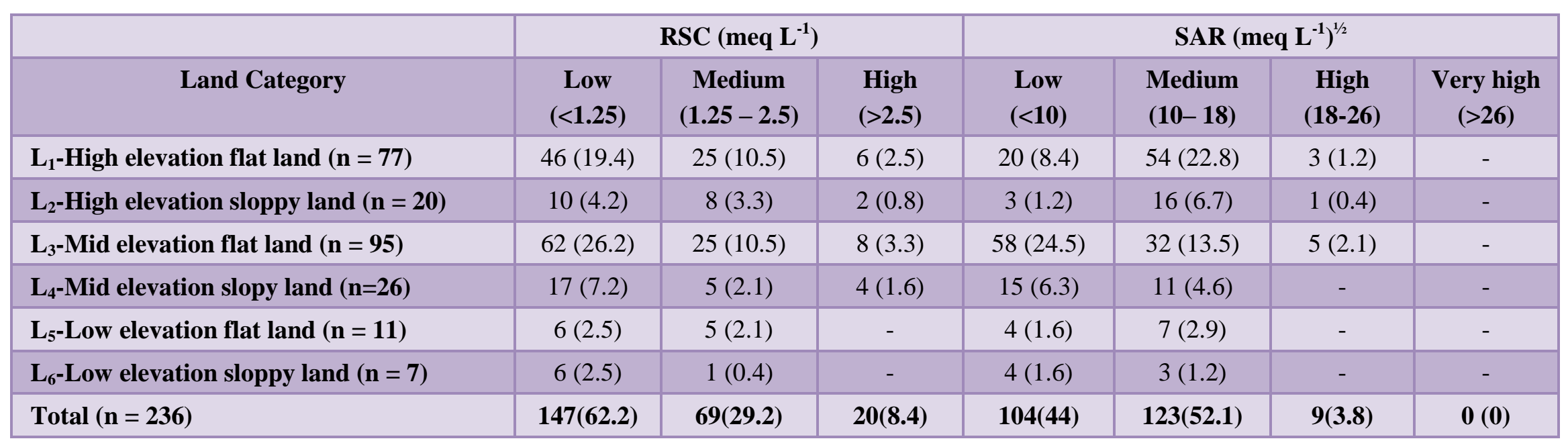


Table.3 Extent of soluble sodium percentage (SSP) and alkalinity fraction in black soils of Ramthal project area

\begin{tabular}{|c|c|c|c|c|c|c|}
\hline \multirow[b]{2}{*}{ Land Category } & \multicolumn{3}{|c|}{ Soluble Sodium Percentage } & \multicolumn{3}{|c|}{ Alkalinity Fraction } \\
\hline & $\begin{array}{l}\text { Low } \\
(<60)\end{array}$ & $\begin{array}{l}\text { Medium } \\
(60-75)\end{array}$ & $\begin{array}{c}\text { Low } \\
(<60)\end{array}$ & $\begin{array}{l}\text { Medium } \\
(60-75)\end{array}$ & $\begin{array}{l}\text { Low } \\
(<60)\end{array}$ & $\begin{array}{l}\text { Medium } \\
(60-75)\end{array}$ \\
\hline $\mathrm{L}_{1}$-High elevation flat land $(\mathrm{n}=77)$ & - & $4(1.6)$ & - & $4(1.6)$ & - & $4(1.6)$ \\
\hline $\mathrm{L}_{2}$-High elevation sloppy land $(\mathrm{n}=\mathbf{2 0})$ & - & - & - & - & - & - \\
\hline $\mathrm{L}_{3}$-Mid elevation flat land $(\mathrm{n}=95)$ & $4(1.6)$ & $26(11.0)$ & $4(1.6)$ & $26(11.0)$ & $4(1.6)$ & $26(11.0)$ \\
\hline $\mathrm{L}_{4}$-Mid elevation slopy land $(\mathrm{n}=\mathbf{2 6})$ & - & $7(2.9)$ & - & $7(2.9)$ & - & $7(2.9)$ \\
\hline $\mathbf{L}_{5}$-Low elevation flat land $(n=11)$ & - & - & - & - & - & - \\
\hline $\mathbf{L}_{6}$-Low elevation sloppy land $(n=7)$ & - & $3(1.2)$ & - & $3(1.2)$ & - & $3(1.2)$ \\
\hline Total $(n=236)$ & $4(1.6)$ & $40(16.9)$ & $4(1.6)$ & $40(16.9)$ & 4 (1.6) & $40(16.9)$ \\
\hline
\end{tabular}

Fig.1 Effect of slope and elevation on $\mathrm{pH}$ and $\mathrm{EC}$

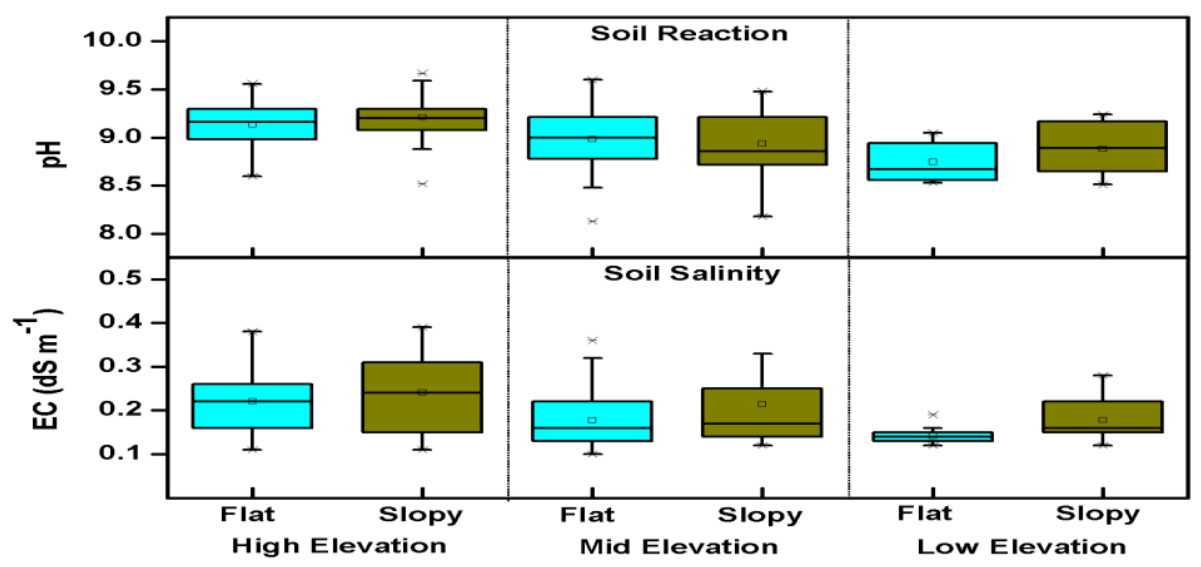

Fig.2 Effect of slope and elevation on RSC and SAR

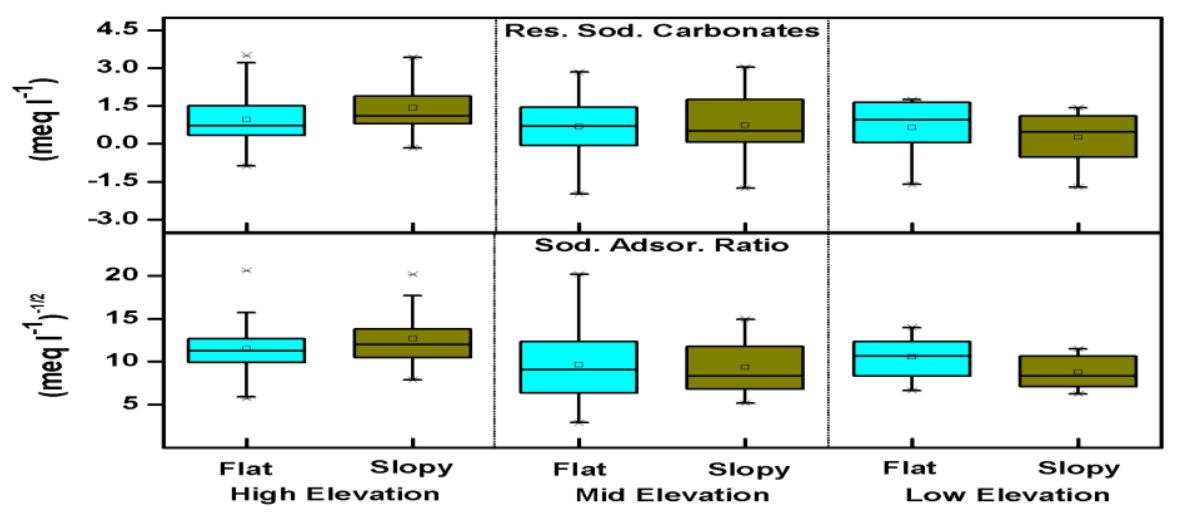


Fig.3 Effect of slope and elevation on soluble sodium percentage (SSP) and alkalinity fraction

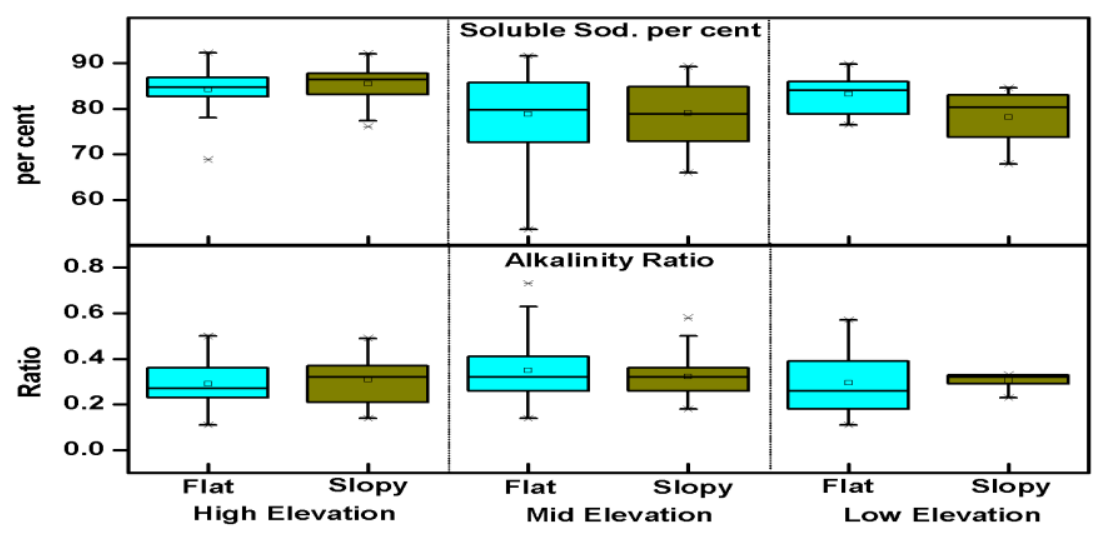

Thus, the cations present in soil water are preferentially retained on soil colloids during capillary movement of water (Bohn et al., 2001; Tan, 2013). Similar reports on dominance of divalent cations were also reported by Yogeeshappa et al., 2013; Anita et al., 2018; Rekha et al., 2018; In other words, there is more mobility of $\mathrm{Na}^{+}$than divalent cations $\left(\mathrm{Ca}^{2+}\right.$ and $\left.\mathrm{Mg}^{2+}\right)$. This could be the reason for observing significantly higher RSC and SAR values at higher elevations (Bohn et al., 2001; Tan, 2013).

\section{Soluble sodium percentage (SSP) and alkalinity fractions}

The dominance of sodium and associated risks of sodification can also be measured by its relative proportion to the total cations present in soil water extract as soluble sodium percentage (SSP) and alkalinity fraction. The corresponding SSP and alkalinity values of soils representing different slopes and elevations are presented in Table 3 and Figure 3. The SSP values ranged from 53.6 to 92.3 per cent and $>80$ per cent of the soil samples $(n=192)$ were observed with high SSP values. Only four soil samples were observed in low sodicity risk category with $<60$ per cent SSP values. The areas situated at higher elevations on slopy $\left(\mathrm{L}_{2}\right)$ and flat lands $\left(\mathrm{L}_{1}\right)$ exhibited significantly high SSP values of $85.5 \pm 4.2$ and $84.3 \pm 4.3$ respectively. The soils present on sloppy land at lower elevations $\left(\mathrm{L}_{6}\right)$ recorded significantly lower values (78.2 \pm $6.2 \%$ ). Thus, the soils existing at higher elevations indicated higher sodicity risks compared to the soils existing at mid and low elevations (Figure 3).

The alkalinity fraction ranged from 0.14 to 0.69 (a ratio without any units). Nearly 80 per cent of the soil samples $(n=186)$ were observed with medium alkalinity values. High alkalinity values of $>0.4$ were recorded in about 15 per cent of samples $(n=35)$. The values of alkalinity fraction of different soils and its spread across Ramthal study area is presented in table 3 and depicted in figures 2 . In the study area the alkalinity fraction ranged from 0.14 to 0.69 . > 70 per cent of the soil samples $(n=186)$ were in medium alkalinity values. All the samples were significantly different.

These two indices also indicated that high elevated areas were more susceptible for sodification. This could be due to precipitation of exchangeable-Ca as respective carbonates during alternate wetting and drying cycles. Solubility of $\mathrm{CO} 2$ in soil water at high temperature might have 
enhanced such precipitation reactions (Bohn et al., 2001; Tan, 2013).

\section{Sodicity risks for horticultural crops}

These observations clearly indicate the sodification risks associated in the Rmathal Micro-Irrigation project area. Sodifiction in soils can induce specific ion toxicities especially for vines, stone fruits, beans and potatoes. Meanwhile, nutrient imbalance in terms of uptake of $\mathrm{Ca}$ and $\mathrm{Mg}$ by plant roots can also be anticipated. Thus, periodical monitoring of these soils and introduction of suitable midterm corrections are necessary to achieve higher productivity in these water scarcity semi arid regions.

\section{References}

Anita, E.K., Prashant, C.T., Champa, B.V., Shivanna, M. and Nagaraja, M.S., 2018, Secondary and micronutrient status in soils of wine and table type grape orchards of northern Karnataka. International Journal of Chemical Studies, 6(3): 2335 - 2338.

Ashwin, H. S., Irappa N. Nagaral, Ashok S. Alur and Nagaraja, M. S., 2017. Effect of different irrigation water sources on soil sodification in typical black soils of Karnataka, International Journal of Current Research, 9 (02): 4727847280.

Baruah, T.C. and Barthakur, H.P., 1999, Text Book of Soil Analysis. Vikas publishing House Pvt. Ltd. New Delhi.

Bohn, H. L., Meneal, L. B. and Connor, O. A., 2001, Soil Chemistry, John Wiley and Sons.

Chhabra, R., 1996, Soil Salinity and Water Quality, Oxford and IBH publishing Co. Pvt. Ltd., New Delhi.

Dattaraja, H.S., Pulla, S., Suresh, H.S., Nagaraja, M.S., Srinivasamurthy, C.A. and Sukumar, R., 2018, Woody-plant diversity in relation to environmental factors in a seasonally dry tropical forest landscape, Journal of Vegetation Science, 29 (4): 704-714.

Doddamani, V.S., Bidari, B.I. and Hebsur, N.S., 1994, Physical and chemical features of soils of upper Krishna project derived from diverse parent materials. Karnataka Journal of Agricultural Science, 7(2): 146-149.

Kirankumar S, Nagaraja MS, Suma R, Ashok Alur S., 2015, Extent of soil sodification as influenced by different irrigation water sources in a typical black soil of Karnataka, An Asian Journal of Soil Science, 10: 159-162.

Lakshmi, P.D., Nagaraja, M.S., Prasanna, S.M., Shankara Meti and Tanveer, A., 2018, Vertical distribution of cations and anions along the slope in a vertisol of dry land areas representing northern dry zone of Karnataka, International Journal of Chemical Studies, 6(5): 1617-1620.

Nagaraja, M.S., Bharadwaj, A.K., Prabhakara Reddy, G.V., Srinivasamurthy, C.A., Sandeep Kumar, 2016, Estimations of soil fertility in physically degraded agricultural soils through selective accounting of fine earth and gravel fractions. Solid Earth, 7:897-903.

Pradeep, R., Dasog, G.S. and Kuligod, V.S., 2006, Nutrient Status of Some Groundnut Growing Soils of Upper Krishna Command Area, Karnataka, Karnataka J. Agric. Sci., 19(1): 131133.

Rekha, M.V., Kirankumar, S., Ashok Alur, S., Nagaraja, M.S. and Suma, R., 2015, Effect of irrigation water sources on micronutrients availability in a typical black soil of northern Karnataka. Andhra Pradesh Journal of Agricultural Sciences, 1:75-79.

Rekha, M.V., Anita, E.Kondi, Champa, B.V., 
Ashok, S. Alur and Nagaraja, M.S., 2018, Fertility Status of Major Cropping Systems Existing in Black Soils of Mudhol Taluka of Northern Karnataka, India, International Journal of Current Microbiology and Applied Sciences, 7(05): 2829-2836

Rengasamy, P., 2010, Soil processes affecting crop production in salt-affected soils. Fundamentals of Plant Biology, 37:613-620.

Rengasamy, P. and Sumner, M.E., 1998, Processes involved on sodic behaviour. In Sodic Soil: Distribution, Management and Environmental Consequences, Sumner, M.E. and Naidu, R. (eds). Oxford University Press: New York; 35-50.

Rudramurthy, H. V. and Dasog G. S., 2001, Properties and genesis of associated red and black soils in north Karnataka. Journal of Indian Society of Soil Science, 49: 301-309.

Sarma, V.A.K., Krishnan, P. and Budhihal, S.L., 1987, Laboratory Methods, Technical Bulletin, No. 14, NBSS LUP. Nagpur, pp. 89.

Sharanagouda, S.M., Nagaraja, M.S., Suma, R., Prasanna, S.M. and Kantesh, G., 2018, Micronutrient availability status among land categories irrigated with different water sources in Bilagi and Bagalkot Talukas, International
Journal of Chemical Studies 2018; 6(5): 2831-2834.

Sharma, D.K. and Chaudhari, S.K., 2012. Agronomic research in salt affected soils of India: An overview. Indian Journal of Agronomy, 57: 175-185.

Shivakumar, K.M. and Nagaraja, M.S., 2016. Micronutrient status in soils of chilli grown areas of UKP command area, Karnataka, An Asian Journal of Soil Science, 11(2): 337-340.

Shivakumar, K.M., Nagaraja, M.S., Champa, B.V. and Kuligod, V.B., 2010. Response of chili to applied nutrients and its influence on important soil properties in the upper Krishna project command. Karnataka Journal of Agricultural Science, 23: 437-441.

Singh A.K. and Verma S.K., 2016, Hydrophysical Properties and Solute Movement in Black Alkali Soils. In: Dagar J., Sharma P., Sharma D., Singh A. (eds) Innovative Saline Agriculture. Springer, New Delhi

Tan, K.H., 2013. Principles of Soil Chemistry, CRC Press, London.

Yogeeshappa, H., Tolanur, I.S. AND Lakshmipathi, N.R., 2013, Studies on physico-chemical properties of different vineyards in Bijapur Taluk, Karnataka. African Journal of Agricultural Research, 8(16): 14771481.

\section{How to cite this article:}

Lakshmi, P.D., M.S. Nagaraja, Shankara Meti, R. Suma, C.N. Pallavi and Anita E. Kondi. 2019. Evaluation of Sodicity Indices for Non-saline Sodic Soils of Ramthal Micro Irrigation Project Area of UKP and their Associated Risks for Horticultural Crops. Int.J.Curr.Microbiol.App.Sci. 8(02): 349-357. doi: https://doi.org/10.20546/ijcmas.2019.802.040 